\title{
NUP98/RAP1GDS1 Fusion Protein
}

National Cancer Institute

\section{Source}

National Cancer Institute. NUP98/RAP1GDS1 Fusion Protein. NCI Thesaurus. Code C99375.

A fusion protein encoded by the NUP98/RAP1GDS1 fusion gene. This protein is comprised of the N-terminal nucleoporin GLFG repeat domains of nuclear pore complex protein Nup98-Nup96 fused to all but the first methionine of the Rap1 GT Pase-GDP dissociation stimulator 1 protein. 